\title{
Empowerment Management Model of Batik Craftsman Entrepreneurship Development
}

\author{
Adhi Iman Sulaiman ${ }^{1}$, Fatmah Siti Djawahir ${ }^{2} \&$ Toto Sugito $^{1} \&$ Sri Weningsih ${ }^{3}$ \\ ${ }^{1}$ Department of Communication Science, Jenderal Soedirman University, Indonesia \\ ${ }^{2}$ Department of Sociology, Jenderal Soedirman University, Indonesia \\ ${ }^{3}$ Indonesia Open University in Purwokerto, Indonesia \\ Correspondence: Dr. Adhi Iman Sulaiman, Departement of Communication Science, Jl. Prof DR. HR Boenyamin \\ No.708, Purwokerto Sub-District, Banyumas Regency, Central Java Province. E-mail: adhi.2005unsoed @ \\ gmail.com
}

Received: September 15, 2019; Accepted: September 30, 2019; Published: October 1, 2019

The research is financed by Ministry of Research, Technology and Higher Education of the Republic of Indonesia and Institute for Research and Community Service in University of Jenderal Soedirman.

\begin{abstract}
The Batik is a craft community that has been the identity, uniqueness, and culture riches that needs to be preserved. The study aims to create empowerment management model of batik craftsmen entrepreneurship development. The study and analysis used Research and Development methods. Data is collected through observation, deep interview, and documentation. The informant has been decided by purposive sampling, namely batik craftsmen, high school student as a generation of batik and batik observers. The research location in Susukan, Banjarneara district of Central Java Province at Indonesia. The results showed that (1) The lack of young generation of batik craftsmen, thus it requires development management through community empowerment of younger generation to preserve local cultural riches. (3) The empowerment management could be designed comprehensively and continuously by involving all parties namely the community, government, universities and private parties.
\end{abstract}

Keywords: batik, craftmen, empowerment, entrepreneurship, management

\section{Introduction}

Local wisdom owned by Indonesia people including the products of cultural arts in the form of batik has uniqueness and privileges that must be inherited and preserved. According to Musman and Ambar (2011) UNESCO decided that Indonesian batik was a cultural heritage since October 2009.Pudjowati et al. (2019) explained that the batik business provided benefits to batik craftsmen and entrepreneurs. However, there is a problem, that is the unequal prosperity caused by the unimplemented empowerment to batik craftsmen.

There is a batik center in Central Java, one of which is in Banjarnegara District, namely in the Susukan Subdistrict, specifically the Gumelem Village which is close to the boundaries of the Banyumas area. But Gumelem batik is not as famous as the Banyumas batik, Solo batik and Pekalongan batik. Therefore, it requires the development of productivity, patterns, promotions and marketing. In addition, Gumelem batik can be popular and used in large scale by the public and with affordable prices, but don't let Gumelem batik lose its characteristics as local wisdom. According to Vitasurya (2016) local wisdom is a combination of reason and behavior in managing changes in the physical and cultural environment based on local knowledge and experience. Keraf (2010) explains local wisdom as people's understanding and knowledge about interactions, relationships and customs about nature, and humans in the development process.

Based on the research results by conducting interviews with batik craftsmen in Gumelem Village and documentation analysis (2018-2019) that Gumelem Batik, which is already well-known, is part of the Susukan Subdistrict, especially in the Gumelem Kulon and Gumelem Wetan Villages, but all the batik products around it, even though they are not from Gumelem Village, are still referred to and are famous for Gumelem Batik.

The Gumelem area has a distance of $40 \mathrm{~km}$ to the west towards the capital city of Banjarnegara, Gumelem has many Small and Medium Enterprises (SME) of batik craftsmen. There is a historical relationship between 
Banyumas batik and Gumelem batik, that has the same characteristics such as the Kawung motif, in Gumelem batik it becomes ginger, kawep ceplokan, pring sedapur and godong lumbu. Batik Gumelem has typical batik patterns of the palace that are classic such as Sidoluhur and Sidomukti. Since the Diponegoro war with the evacuation of Prince Puger to the Banyumas region, Gumelem batik cloth has begun to be famous, because it was brought by batik culture of the palace as the center of all royal activities. In the refugee camp as a new location, batik was developed with the tastes and styles or motives of the local community, including the Gumelem batik. Batik in Central Java has a glory center by having unique patterns and patterns such as in Solo, Yogyakarta and the Pekalongan area. Meanwhile the characteristics of Gumelem batik are senthe salad and udan lyris made as a hereditary culture whose characteristics have dominant colors such as black, yellow and brown as well as floral patterns.

Findings from researchers (2018-2019) that there is a problem in the batik business in the batik writing group of the Batik Wardah, namely a start-up business, the huge capital required and careful management needed. Moreover the marketing has not been able to use technology that need to be developed by craftsmen, so that the craftsmen need to improve knowledge and ability to promote and market with digital media. Business groups that employ batik craftsmen are generally old, thus threatening the preservation and cultural heritage of batik among generations. This is because batik training for beginners is still minimal, so that only a few people make batik and most of them are old. The technology used in batik has not used modern or applied technology both in terms of making motif designs and production processes. Yet it still uses conventional techniques with design and handheld processes. The application of technology for batik requires high cost that is sometimes less affordable by batik craftsmen. Moreover the business problems in the craftsmen business group both in the Gumelem batik group of The Gumelem Wetan Village and the Wardah batik group in Panerusan Village, Susukan sub-district including batik workers are sometimes disproportionate compared to the number of orders obtained, so the time required for batik to meet consumer demand is time consuming. On the other hand, product marketing still requires special tips or reliable marketing strategies, for example the use of online shop media and the like. Knowledge and ability in using media technology are still limited. Actually the use of appropriate technology in processing batik is needed to make efficient production. Business groups that employ batik craftsmen are old. That is because batik training for beginners is still minimal, so that there are only a few batik makers. There is no standardization of material quality, coloring and price for the Banjarnegara batik entrepreneurs, especially for Gumelem batik in Banjarnegara. According to Nautica and Sayatman (2019) stated that there was no rapid development of batik business and there was no good integration between the activities of economic business groups with community knowledge and skills in the field of production business. Alhusain (2015) explained that the fact that China had already produced batik and entered the Indonesian market had varied patterns and patterns and a much cheaper price. Though the quality of batik produced in Indonesia is better, but the price of Indonesian-made batik is still high compared to the price of batik made in China.

Batik is a unique, attractive business product, a characteristic of Indonesian people's traditions and needs to be preserved and developed both in quality and quantity. Batik is not only a commercial product that can produce material benefits but more than that as a characteristic and cultural product of the Indonesian people so there must be continuous efforts to conduct studies in the orm of research, empowerment and publication about batik. The regeneration of batik business groups in rural communities needs to be given attention continously, accompanied and developed wisely by combining local wisdom and adopting innovation as challenges and demands of the global era (Musman \& Arini 2011); (Purnono 2013); (Puguh 2017); (Mustika 2018).

So the research suggests, that the government sould make policies that support to improvement of the local and and domestic products quality in order to be able to become an economic force and improve welfare and can be exported, and then can anticipate the number of imported products that actually serve as the sinking of local products Utilization of appropriate technology in processing batik is needed to make efficient production. As according to Murni et al. (2011) and Pebrianasari et al. (2015) creativity and productivity of batik crafts can be supported by the adoption of technological innovations such as using backpropagation algorithms to be able to make batik patterns that have more accurate and character documented. Suprapti et al. (2016) states that batik products can also be supported by information technology innovation to develop design, promotion and marketing and establish partnership access.

Therefore based on the findings of researchers and the study of research results, it is important and strategic to create a management model for empowering batik craftsmen in preserving cultural heritage and improving welfare.According to Dogan (2015) the strategic entrepreneurship is based on the integration of entrepreneurship and strategic management. Strategic entrepreneurship is a new approach in the management literature. In addition, the business world today requires an orientation towards strategic entrepreneurship. Strategic entrepreneurship is 
also a must for companies to create maximum wealth. In this study, strategic entrepreneurship which is the intersection of entrepreneurship and strategic management is analyzed. Laguia et al. (2019) as with management, entrepreneurship is closely related to task orientation with more orientation towards the need to pay attention to gender equality especially for women in entrepreneurship education, towards policy makers and the media to promote the image of entrepreneurship.

The researcher confirms that the business group should have a batik business development management through an empowerment program for the younger generation as the successors and preservation of the cultural heritage of batik. Management of business development and empowerment of batik communities must be designed, planned, implemented and evaluated to have a standardization of material quality, coloring and price for batik entrepreneurs, in this case in Gumelem batik, Susukan Subdistrict, Banjarnegara District.

\section{Method}

The study was conducted in 2018 and 2019 by determining the location of the center and two communities of written batik craftsmen namely the Wardah group in the Susukan Subdistrict area, Banjarnegara Regency, Central Java, which has 25 batik business groups. This research uses Research and Development (R\&D) methods that are intended to identify findings, design, work on better conditions, test and develop the effectiveness of products, methods, models, procedures, and strategies so that they are superior, effective, efficient, novelty productive and innovative. Research and Development methods is applied as basic and implementation in the process of improvement and renewal with an emphasis on novelty, creativity and tangible products. Research data were obtained through in-depth interviews, direct observation, focus group discussions, and documentation analysis (Sugiono 2008); (Torok et al. 2015).

The research location was in Panerusan Village, Susukan Subdistrict, Banjarnegara District, there is a Wardah Batik group that has been producing for quite a long time, aproximately a decade, with the results of producing natural and chemical dyed batik. Partisipants are determined by purposive sampling consisting of the chairman and members of the craftsmen business group, high school student as ageneration of batik, and batik observers.

Stages of analyzing research data used Research and Development (Sugiono 2008), that first, analyzing problems and potentials, secondly designing products, thirdly validating product design results, fourth revising product designs, fifth testing product designs, sixth revising products, seventh retesting products, eighth, revising the product, the ninth was mass-producing.

\section{Results}

Based on monograph data from Susukan Subdistrict, Banjarnegara Regency, Central Java in 2018, that Susukan Subdistrict is located at an altitude of $46 \mathrm{~m}$ above sea level with a distance of $38 \mathrm{~km}$ from the city of Banjarnegara Regency. Subdistrict of Susukan area has 15 villages in Susukan Sub-District area that is 45,717 Ha with a population of 3,142 inhabitants, namely 1,566 women and 1,567 men. Mostly they, as many as 553 women and men, work as farmers. There are nine typical Gumelem batik groups in the Susukan District including Panetan Jaya, Nova Batik, Mirah Batik, Setia Usaha, Prana Mukti, Wardah Batik, Ammorista, Mekarsari and Giat Usaha with an average number of batik craftsmen of 20-40 people. Based on the results of interviews and documentation analysis, the history of the emergence of Gumelem batik based on the history of the existence of a perdikan area which eventually became a Gumelem kademangan proven by illustrated images of activities of a palace such as government management systems, economic life, fashion and regulations on a prosperous life independently or autonomously in the village. The kademangan is led by a demang who has a management structure that works and serves, including batik craftsmen to meet the needs of the kademangan family. The ups and downs of the development of Gumelem batik, which eventually worn as daily clothes, lacked of privilege and there are more printed batik than written batik.

However, the further development of Gumelem batik revived around 2009 with the policy of the Regional Head (Regent) No 025/591 of 2009 and No. 51 of 2016 concerning batik as an official uniform that must be worn in the Banjarnegara Regency Government for Civil Servants on Wednesday, Thursday, Friday and Saturday (Widyastuti \& Ardhanariswari 2016). Batik Gumelem comes from the name Kedemangan, which now is a village. Kedemangan is the area of the Yogjakarta palace, so the beginning of batik was from Yogyakarta Kedemangan. Thus, those who brought batik were relatives from Kedemangan Yogyakarta to the villages of Panerusan Wetan, Panerusan Kulon, and surrounding areas. In early 2000, in Gumelem Village only made batik with canting and coloring activities in Sokaraja. Then the government considered how Gumelem batik could produce batik cloth as a whole, without having to do coloring activities in other areas. 
In certain regions, batik industry is still done traditionally as a part time or casual job. The results of traditional batik crafts have patterns, patterns, coloring and styles that have different characteristics. Banjarnegara with Gumelem batik as a center for batik crafts also has different coloring and patterns from other regions such as Yogyakarta, Surakarta and Pekalongan. The specificity of Gumelem batik is that it displays colors with a predominantly dark color that is black and dark brown, while the motif is mostly taken from the natural surroundings. Since 2004, batik in the area of Banjarnegara District has shown an encouraging development of around 22 batik craftsmen. Then the data obtained from the Economy Section of the Regional Secretariat of Banjarnegara said, in 2018 the number of Gumelem written batik craftsmen were recorded around 400 people from the original number in 2003 which were only 22 people. According to informants in Panerusan Wetan Village, one of the craftsmen helped raise the existence of "Gumelem" batik. Among those studied were the batik production house named the Wardah batik group which was pioneered in 2010. It has two types namely modern batik and classic batik. Classic batik has a high value and characteristics because the stages of the process in making it takes between 3 to 4 weeks and is quite complicated, so the price is quite expensive. Classic batik has basic patterns with a variety of patterns, such as machetes, patches, kawung, truntum, dots, and fried. Moreover, the basic material of batik is white cloth with fine quality cotton and white fabric from silk that will produce batik with more vibrant colors.

On the other hand, the modern batik, its coloring does not depend on such as polarization and color on classical batik, but can be produced with a variety of various patterns and patterns (Borshalina 2015). Modern batik can use materials and the coloring process by following progress or development. Modern batik has used brushes to replace canting and coloring using cloth or cotton. So that the modern batik making process is similar to classical batik, but the difference in the coloring process and the pattern depends on the tastes of the maker and buyer.

\section{Discussion}

\subsection{Development of Batik Craftsmen Enterpreneurship}

The total number of batik makers in Susukan Sub-district is recorded as 142 people, but in general there are human resource problems that is the difficulty of finding a replacement or regeneration in making batik cloth. The average worker in this business group is around 40 years old. The Wardah batik group also experienced the same difficulties from finding the successor of batik because of the low awareness and interest in making batik from the younger generation so that it has an influence on the business activities being run into production shortages. Batik craft is a small-scale industrial entrepreneurship but has huge and prospective potential, so according to Lukuma et al (2019) it needs government support such as organizing skills upgrading for batik generation among students as non-formal and formal education material in order to foster love, care and preservation of cultural batik regions, then provide business capital to batik craftsmen in developing their business. Sudantoko (2010) suggested the implementation of community empowerment programs in the development of batik businesses including strengthening business institutions, expanding market access, increasing the ability and expertise of human resources and technology adoption. Suliyanto et al. (2015) the importance of managing the development of batik, especially for young people with learning activities in training in active participation in all aspects of activities ranging from planning, implementing, to the stage of assessing learning activities in training. Permatasari (2018) that business groups can create products and services with value creation, cooperative relationships, prices in accordance with market demand.

Gumelem Batik has become an icon or symbol of written batik in Banjarnegara, precisely in Susukan District, while the name Gumelem itself is in two villages namely Gumelem Kulon and Gumelem Wetan. However, the results of batik crafts from the villages around Gumelem, are known as Gumelem batik as Wardah batik group from Pangrengan Village, Susukan District, which was established in 2010 and whose owners have long been batik artisans working together with other batik makers. But Gumelem batik craftsmen have not yet finished making batik, because in Banjarnegara there is no place for coloring batik, so the coloring is done in the Sokaraja Banyumas area. Therefoor it requires empowerment and development management.

The next developments, batik makers received government support by providing venture capital assistance. Then Wardah batik group began to take the initiative to start learning to do their own coloring, so they could finish the batik cloth as a whole and be ready for sale. Bonita (2013) states that the implementation of the empowerment program for batik craftsmen must involve active participation from all parties ranging from the government, academics, non-governmental organizations, the private sector and batik business men. Mahto and MacDowell (2019) stated in entrepreneurial management can develop motivation as an important factor as an entrepreneurial exposure in social environments. 
The group succeeded in learning the coloring process so that they could do their own batik coloring, therefor the batik group tried to recruit other batik makers to join in their efforts to produce batik by themselves until finishing, that's when the batik craftsmen group began to develop, by having done their own coloring.

Batik groups often attend exhibitions such as at the JCC (Jakarta Convention Center) on March 2017 and at the PRJ (Pekan Raya Jakarta) requested by the Regional Government of Jakarta. Besides batik groups follow exhibitions such as in the city of Batam. Social media and print media play an important role to be utilized as a promotional media so that it becomes more popular and much in demand. The more published in the media, the more the public knows and the number of enthusiasts in batik from the public. Susanti and Mas,udah (2017) emphasized the importance of empowering batik artisans to improve their knowledge and abilities in improving product quality through training in batik coloring and financial management and marketing. Sudantoko (2011, Karwati and Mulyono (2018) states that organizing empowerment activities through training as an effort to cultivate entrepreneurship by providing small business marketing venues such as kiosks or factory outlets. As according to Farida et al. (2017) batik handicraft products require promotion and marketing strategies such as participating in various exhibitions in the domestic and overseas regions and through communication technology media such as through e-commerce sites such as several applications or online advertising media.

Gumelem Batik mostly has patterns in Banjarnegara that have culinary or tourism characteristics. Most of them are things in Banjarnegara, but there are also other patterns. The batik used has smooth quality and well known from Banjarnegara, Banyumas to National level. The meaning of smooth batik is batik that is neatly written and small. It doesnt mean smooth fabric. The batik craftsmen group built a business as a home industry and recruited useful batik makers by creating jobs for the surrounding community and increasing community income. According to Murni et al (2011), Puspitaningtyas et al (2014) craftsmen in small industries bring important benefits in increasing the income and welfare of workers. Likewise Syamwil et al., (2015) conducted training and workshops on developing the batik industry for the community to increase enthusiasm, knowledge and skills as well as productivity.

There are various types of pure batik production, semi-written batik, batik with a stamp system, and batik with a printing system. There are 715 pieces of batik produced each month, namely 220 sheets of semi-written batik, 17 pieces of pure batik, and 510 sheets of printed batik. The batik production of 45 workers was batik and 4 were coloring workers. There is a sense of worry about the existence of Gumelem batik, because the two-dimensional art performer is dominated by batik craftsmen aged 50 years and over and there are only a very few of them. Therefore, in order to preserve the existence of Gumelem batik, there is an effort to regenerate by training several young generation, including creating participatory opportunities and media for young people or students who have the determination, enthusiasm, and interest to make batik. Regarding marketing so far it has not been a major problem, because buyers generally come alone to locations that already know the peculiarities and qualities of Gumelem batik. Most of the production is based on orders and some others are marketing in the area of Semarang and Jakarta.

Batik has a price range of between 170 thousand rupiah to more than 1 million. The patterns that are often produced include Dawet Ayu, Langsat Salak, Kawung Salak, Naga Fruit, Twin Semanggen, Bali Banana, Haji Fern, Sirongge, Raflesia, Sea Clump, Pring Sedapur, Pring Setetek, Parang Mrica, Laras Pongas, Sekar Kupu and patterns the other.

This Batik group has problems in human resources and coloring. Batik craftsmen in this batik group are mostly above 50 years old and the rest are 30 to 40 years, there is no young batik craftsmen. Batik lacks of human resources in making batik, that is the lack of regeneration of young batik. The lack of young batik craftsmen is caused by the lack of awareness and the lack of interest in the younger generation in batik. They are lazy and prefer to play with their peers and play on the internet media that are considered more modern and attractive compared to batik that looks more traditional or considered old-fashioned and outdated. To anticipate the lack of awareness and interest of the young generation in the village of the batik culture, batik learning activities are carried out free of charge at the place of batik, for anyone who wants to learn especially teenagers in their particular village and generally outside the village is also free of charge. There are some who have learned and the results are good, but after a while they no longer return to the place of batik because they are busy. The awareness and desire of the young generation are still weak, because they also do not think they will make batik until they finish school. Young people nowadays prefer to study outside the city or look for a job in a big city.

Therefore they do not make batik as the main income and the main profession, because they know that earning a steady income such as in the office will be more sufficient to meet their daily needs compared to make and sell batik. On the other hand we can see that the income from batik is not fixed, it can exceed the office income and 
can create jobs for the surrounding community who do not have jobs. Young people think that being a batik craftsman is a less prestigious job because it is still traditional, even though batik is a characteristic and culture that has been done and passed down by the community and family. Batik should be preserved as a culture that has been given by the ancestors, so that it is not extinct and can become a local pride and wisdom. The young generation has potential, high creativity and has interesting ideas in the midst of information era and communication technology that is easy to find sources of knowledge, many examples that can be copied and there are many open marketing access. According to Geertz (2007) local wisdom is the ability to respond and empower all potential sources, especially the noble, unique and distinctive cultural values in a community or entity that characterizes and determines the dignity of the community. Samudra (2010) states that local wisdom is the intellectual and ideas of local communities that contain good value, wisdom which have become the behavior and culture of the people.

Another problem is the coloring process. Some of the coloring fails. Making batik even though the color is the same but the pattern will be different because the makers of the batik are also different. In coloring using chemical dyes will often be different because batik craftsmen do not know how long the dye has been made, so there is batik that has different color and the result becomes unusable. There are some batik that can not be used at all so it must be discarded, but there are some batik that can still be found ways to be used. Batik that fails and can still be remade can not be written anymore, but it must be completely removed and replaced with screen printing or printing. It could be made into other clothes, and if necessary will be reprinted again.

The coloring must also be in one time compounding otherwise the color will not be exactly the same as the color of the first concoction. This will have an impact on consumers who are dissatisfied because the results of different colors and even some who do not want to accept it. In contrast to batik printing or stamp, the coloring can be arranged by using a mixture that is measured because it uses a machine, whereas writen batik cannot match the composition of the concoction, moreover the batik makers are different. Another thing with batik printing will be coloring because it uses a machine while written batik is purely handwritten. And batik itself if used for 1 year by people will be varied in colors depending on how they care batik, there are still good batik, there are colors that have faded, because the way they treat batik is different, from the process of washing, drying and even storage. All depends on each person.

Consumers also have the knowledge that not all batik is the same because the writing of batik with different people, so consumers can receive the batik with understanding and satisfaction. Batik that fails and is not accepted by consumers will make batik losers, the cause is because sometimes there are errors from coloring. But if consumers are disappointed and still do not want to accept the batik, the seller quickly returns to the craftsman, if it cannot be repaired then it will be proceeded with the screen printing process and use batik printing.

Another problem is the negative impact of the results of the process of making written batik which results in liquid waste that is sourced from coloring drugs and batik whitening drugs that make pollution in the form of waste water and discharged into rivers in residential environments. Liquid waste generated from batik dyeing remnants that enter the category of hazardous pollution (waste) and toxic materials abbreviated, which is the most dangerous pollution in the batik industry through the process of dyeing in a chemical solution with a medium of water and wax oil, starch and detergent as an additional ingredient.

According to Ngatindriatun et al., (2014) and Jakaria et al. (2018) there are still many batik craftsmen who use synthetic dyes instead of using natural dyes, so they are still protecting the environment, especially rivers. Protecting and preserving the environment so that it is not damaged as a result of synthetic coloring in batik production is a form of local wisdom. As according to Efendi (2014) local wisdom can preserve and control the environment based on values and culture that become the lifestyle of a community. This is important because the environment is experiencing degradation due to the negative impacts of large and uncontrolled population and the impact of globalization.

The negative impact of batik can also be felt by batik craftsmen, namely the risk of skin diseases caused by the coloring process. Generally craftsmen do not use security for hands (gloves), even if they use gloves they do not use them properly, so they are less protected. The impact on the hands from the chemicals is dangerous batik dye, naptol. Inapropiate disposal of batik staining waste can result in pollution to ecosystems, both land and rivers. Then another impact is the lack of attention to the children of batik craftsmen because the work of the written batik is very busy to complete their work so that they can meet the needs of their families. It results in the lack of attention to their children. This develops empowerment management in batik, which was previously only able to make batik without coloring, but now they have been able to make batik and coloring, thus creating independence. Based on Law No. 20 of 2008 concerning Micro, Small and Medium Enterprises (MSMEs), the empowerment 
program is an effort of the government, the community and the private sector to establish, develop, and provide entrepreneurial assistance in MSMEs. According to Ihsaniyati et al. (2017) states that the empowerment of batik craftsmen requires empowerment as well as assistance on the completion of batik training, the use of batik finishing tools, making promotional and marketing strategies by following an exhibition (expo) to increase the income and welfare of batik craftsmen. Sulaiman et al., (2016) states that empowerment program is implemented comprehensively starting from counseling, training, mentoring, monitoring and evaluation. Sulaiman et al. (2019) that empowerment of rural communities based on potential and local wisdom could be improve the welfare of economic groups and independence of community as important factors, because the village development is the foundation of regional and national development. Kurniati and Prajanti (2018), Tohari and Sugito (2019) suggest that Batik craftsmen require varied innovations in developing businesses and conducting learning processes both independently and cooperatively by utilizing social capital, so that it needs to be supported by an empowerment program to improve the ability of the craftsmen's innovation.

\begin{tabular}{|c|c|c|c|}
\hline $\begin{array}{l}\text { Potentials and } \\
\text { problems analysis } \\
\checkmark \text { Lack of awareness and } \\
\text { enthusiasm of young } \\
\text { people to learn batik } \\
\checkmark \text { Synthetic dyes is still a } \\
\text { threat of } \\
\text { environmental } \\
\text { pollution } \\
\checkmark \text { The high price of } \\
\text { handmade batik is less } \\
\text { affordable for the } \\
\text { consumers }\end{array}$ & $\begin{array}{l}\text { Product } \\
\text { Design } \\
\text { Batik Gumelem } \\
\text { has a } \\
\text { characteristic } \\
\text { that must be } \\
\text { maintained, } \\
\text { namely the } \\
\text { lyrical udan and } \\
\text { rujak senthe } \\
\text { pattern as local } \\
\text { wisdom }\end{array}$ & \begin{tabular}{l}
\multicolumn{1}{c}{ Product } \\
Validation \\
Batik \\
Gumelem \\
product has \\
been famous \\
and sought by \\
consumers \\
and become \\
identity
\end{tabular} & \begin{tabular}{l}
\multicolumn{2}{c}{ Design } \\
Revision \\
Characteristic \\
Gumelem batik \\
pattern can be \\
made with \\
natural dyes \\
from plants that \\
are more \\
friendly to the \\
environment
\end{tabular} \\
\hline $\begin{array}{l}\text { Product Revision } \\
\\
\checkmark \text { Revised program } \\
\text { of trials that have } \\
\text { been conducted to } \\
\text { improve the } \\
\text { quality of patterna } \\
\text { and natural colors } \\
\checkmark \text { Make } \\
\text { modifications and } \\
\text { innovations in } \\
\text { written batik } \\
\text { pattern }\end{array}$ & $\begin{array}{l}\text { Trial Usage } \\
\text { After the lab } \\
\text { test batik } \\
\text { products will be } \\
\text { tried with } \\
\text { natural dyes } \\
\text { both in strength } \\
\text { and color } \\
\text { quality }\end{array}$ & $\begin{array}{l}\quad \text { Product } \\
\text { Revision } \\
\text { Requires } \\
\text { laboratory tests } \\
\text { at Unsoed to } \\
\text { improve the } \\
\text { natural color } \\
\text { quality of plants }\end{array}$ & $\begin{array}{l}\text { Product Trial } \\
\text { There are } \\
\text { already } \\
\text { handmade batik } \\
\text { products with } \\
\text { natural dyes } \\
\text { from plants and } \\
\text { the results are } \\
\text { softer and not as } \\
\text { sharp as } \\
\text { synthetic colors }\end{array}$ \\
\hline \multicolumn{4}{|c|}{$\begin{array}{l}\text { Mass Production } \\
\checkmark \text { Carrying out management of entrepreneurship development of batik craftsmen with } \\
\text { comprehensive and continuous empowerment program from planning, implementating anc } \\
\text { evaluating training, mentoring, monitoring and evaluation activities, institutional anc } \\
\text { marketing development, partnerships and independence. } \\
\checkmark \text { Increasing the interest, motivation and potential of the young generation to preserve batil } \\
\text { and batik entrepreneur } \\
\checkmark \text { Increasing the production of handmade batik with natural dyes for sale to the market } \\
\checkmark \text { Making mass products for office uniforms in government, schools and colleges to help the } \\
\text { level of sales and prosperity for batik craftsmen }\end{array}$} \\
\hline
\end{tabular}

Figure 1. Batik Craftsman Entrepreneurship Empowerment Management Model 


\subsection{Batik Craftsman Entrepreneurship Empowerment Management Model}

Based on the factual development of Gumelem batik, especially in the Wardah batik craftsmen group, batik empowerment stages can adopt the Research and Development Method to create a model of empowering management and development of batik craftsmen which adopts and compiles a model from Sugiono (2008) and Torok et al. (2015), as in Figure 1.

Implementing the empowerment management model and developing batik craftsmen need to get attention from the village and regional governments including representatives of the people to provide lots of training and coaching to make batik in the surrounding community that make the community interested in making batik and adding attraction to batik production results from the group batik. This training and coaching is also used to improve the quality of products that are produced to get better. Thus it requires human resource management in empowerment as according to Watson (1995) the importance of professional companies having entrepreneurship to support business development. Likewise, entrepreneurship must have professional management in order to survive and succeed in developing, otherwise it will collapse. Kadarisman (2013), Sedarmayanti (2013) and Dogan (2015) that the human resource factor is very important and strategic in determining the development of organizational management starting from planning, organizing, actualizing, monotoring and evaluating. Pudjowati et al., (2019) the empowerment of batik craftsmen through batik technique training, they will be able to improve the quality, beauty and attractiveness of products in ordert to increase buyers and income for craftsmen. Poernomo et al. (2017) explained that the development of batik handicraft businesses is determined by the enthusiasm and skills of workers, having capital, completeness of infrastructure, completeness of facilities, raw materials, sales networks, market location, economic institutions such as cooperatives or financial institutions, policy support from the government, training programs, and institutional batik craftsmen.Cahyono, et al (2017) batik is a symbol of cultural heritage inherent in people's homes that needs to be preserved and becomes an attraction for the development of cultural-based entrepreneurship. Kurniati and Prajanti (2018) empowering is a form of community service to increase the value, uniqueness and privilege of batik as a culture and high art, Lin et al. (2019) stated entrepreneurship management having a more reasonable price for craftsmen by improving management of facilities, equipment, and marketing-based information technology.

The results of monitoring and evaluation are very important as input and improvement for the next program planning. Based on this, a batik handicraft entrepreneurship empowerment entrepreneurship management model could be comprehensive and sustainable as shown in Figure 2.

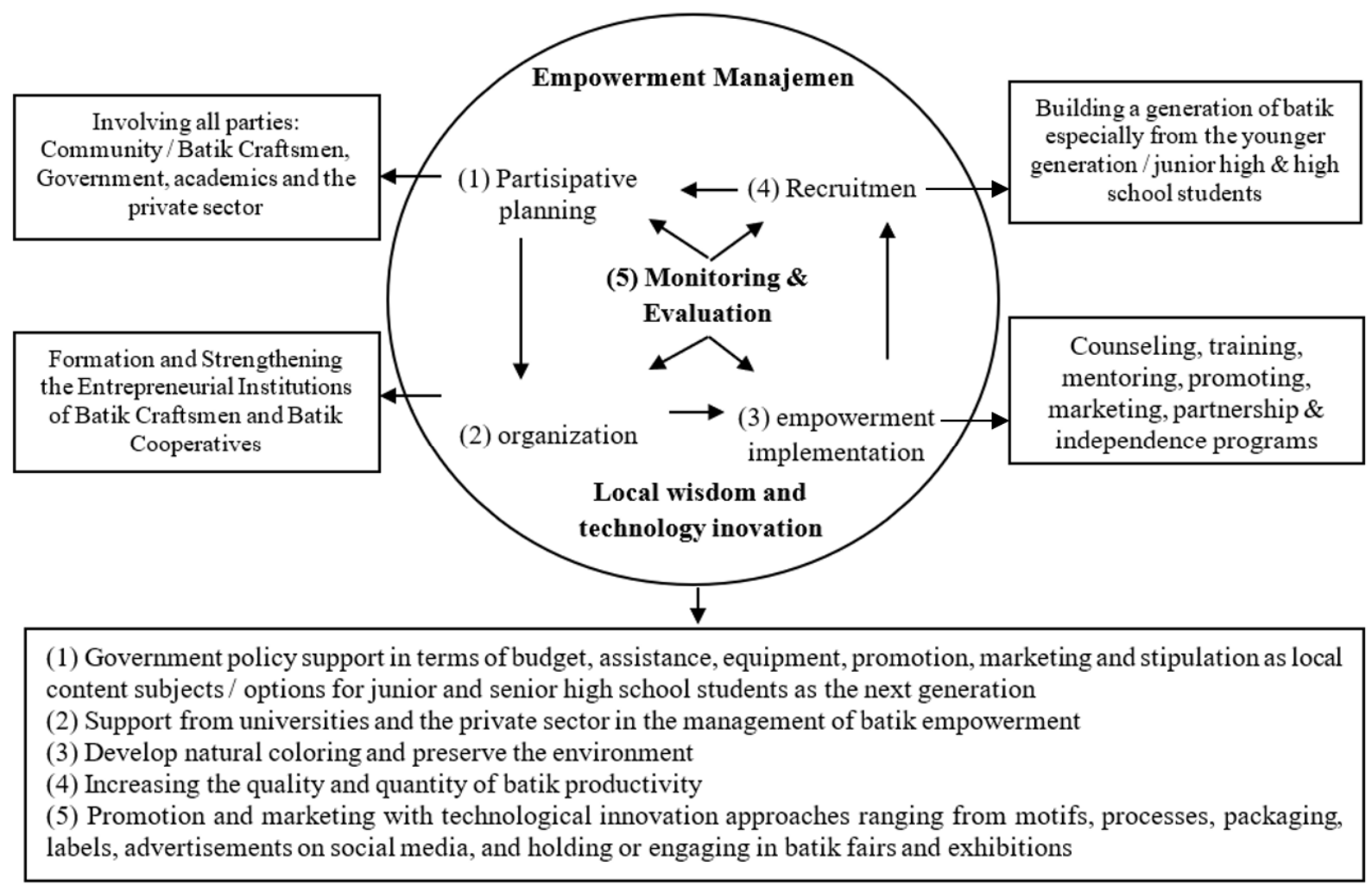

Figure 2. Empowerment Management Model of Batik Craftsmen Enteurpreneurship 
Discussion of the empowerment management model to improve entrepreneurship of batik craftsmen in a comprehensive and sustainable manner starts from (1) the empowerment program planning process carried out in a participatory manner by involving the community, especially batik craftsmen, entrepreneurs and young people with local and village governments supported by budget policies, capital assistance and facilities, promotion, use of batik products for school and office uniforms and marketing with the agenda of batik bazaar activities at the district level. (2) Organizing through the formation and development of batik craftsman institutions that have been formed through training in batik production, packaging, promotion and marketing through technological innovation approaches, and even batik cooperatives can be formed that can collect products, assist in capital and marketing. (3) Implementation of empowerment programs that can be carried out by regional governments in cooperation with universities starting from (a) Counseling to strengthen and increase awareness, interest and enthusiasm in making batik, (b) Making batik training to improve the ability or expertise in making batik, then designing batik, making product packaging, promotion and marketing strategy products with computerized technological innovations and the use of social media. Training in making natural coloring from plants and the movement to maintain environmental pollution. (c) Assistance programs for institutional strengthening, recruitment, product development, promotion and marketing. (d) Program for the formation and strengthening of batik makers, especially from the younger generation both in the village and in a number of junior and senior high schools, such as creating a young batik organization. The institutional development of batik can be made by batik cooperatives to help with capital, production and marketing. (e) The partnership program can work with universities, the private sector and the government especially in the use of batik products for uniforms so as to increase batik productivity. (4) The process of recruitment of batik generation that also prioritizes the younger generation by introducing, providing motivation and skills to junior and senior high school students as the successor generation of batik. Batik making is an additional subject matter and a local item for each school to cultivate enthusiasm, interest and potential to make young generation batik, this needs to be supported by local government policies through the education service in collaboration with related agencies such as the labor, cooperative and MSME sectors. (5) Monitoring and evaluation can be carried out by the regional and village government, as well as by universities that are facilitators or empowerment management facilitators to improve batik entrepreneurship.

\section{Conclusion}

Gumelem batik has become a symbol or characteristic of Banjarnegara batik, although batik products are made in other villages, but are still called Gumelem written batik products. Gumelem Batik began to get the attention and support from the local government to become the official clothing of all agencies at least every Friday and Saturday. This can help to increase production, sales and bring income and welfare guarantees for batik artisans to continue their business. Making batik into local wisdom as a cultural heritage that has attractiveness and uniqueness, can improve the welfare of its people, maintain and preserve the environment so that it is not polluted by the coloring of batik, and there is local government support with its policy of preserving batik both through empowerment management and mandating batik as work uniform in regional government.

Gumelem Batik is still experiencing problems, namely the threat of the next generation or generation of batik from the younger generation who lack of awareness and enthusiasm to continue the cultural heritage to preserve batik and batik entrepreneurship. Batik Gumelem has a problem about the potential for environmental pollution from synthetic coloring, so it has begun to do natural coloring from plant materials that must continue to be developed scientifically.

The empowerment management of entrepreneurship development of batik craftsmen is carried out comprehensively and continuously starting from designing program plans, implementing and monitoring evaluations in the stages of extension activities, training, mentoring, monitoring and evaluation, institutional development and marketing, partnerships to independence.

Empowerment management can be focused specifically on increasing the awareness and motivation of young people to be interested and skilled at making batik, increasing their ability to create and innovate in natural image motifs and types of coloring. Empowerment about the manufacture and improvement of the quality of natural dyes needs to get attention from both the government and universities for laboratory trials and innovation in image motifs.

Empowerment management in developing promotion and marketing, even though it is well known to the wider community, but access and tourist destinations are still not very supportive to Gumelem Batik. So it is necessary to further expand and develop advertisements, promotions and marketing such as attending exhibitions, opening shops outside Gumelem such as in urban areas with easy access to tourists. 
It requires the management of empowering batik craftsmen, especially among middle and high school students, as a subject of local content and specialization options to provide skills and motivation for batik among students and to preserve Gumelem batik.

\section{Acknowledgement}

We extend our thanks to the Ministry of Research, Technology and Higher Education and the Research and Community Service Institute of the University of Jenderal Soedirman (Unsoed) Purwokerto for providing us with the opportunity to carry out competency research and community service activities in 2018 and community partnership program in 2019. This includes the research subjects of the Batik Wardah Craftsmen and Entrepreneurs Groups who have supported and collaborated in the research and community service process.

\section{References}

Alhusain, A. S. (2015). Kendala dan Upaya Pengembangan Industri Batik di Surakarta Menuju Standardisasi. Jurnal Ekonomi \& Kebijakan Publik, 6(2), 199-213. https://doi.org/10.22212/jekp.v6i2.348

Bonita, F. (2013). Strategi Pengembangan Industri Kecil Kerajinan Batik di Kota Semarang. Economics Development Analysis Journal, 2(3), 234-245. https://doi.org/10.15294/edaj.v2i3.1978

Borshalina, T. (2015). Marketing Strategy and the Development of Batik Trusmi in the Regency of Cirebon which Used Natural Coloring Matters. Procedia - Social and Behavioral Sciences, 169, 217-226. http://doi.org/10.1016/j.sbspro.2015.01.305

Cahyono, U. J., Setioko, B., \& Murtini, T. W. (2017). Transformation of form in the growth of modern Javanese house in Laweyan Surakarta. Journal of Architecture and Urbanism, 41(4), 288-295, http:///doi.org/10.3846/20297955.2017.1411848

Dogan, N. (2019). The Intersection of Entrepreneurship and Strategic Management: Strategic Entrepreneurship. Procedia - Social and Behavioral Sciences, 195, 1288-1294. https://doi.org/10.1016/j.sbspro.2015.06.290

Efendi. (2014). Implementasi Kearifan Budaya Lokal pada Masyarakat Budaya Adat Kampung Kuta sebagai Sumber Pembelajaran IPS. Sosio Didaktika, 1(2), 211-218. http:///doi.org/10.15408/sd.v1i2.1263

Farida, N., Naryoso, A., \& Yuniawan, A. (2017). Model of Relationship Marketing and E-Commerce in Improving Marketing Performance of Batik SMEs. Jurnal Dinamika Manajemen, 8(1), 20-29. https://doi.org/10.15294/jdm.v8i1.10408

Geertz, C. (2007). Kebudayaan dan Agama. Yogyakarta: Kanisius Press.

Ihsaniyati, H., Wijianto, A., Suminah., \& Anantanyu, S. (2017). Pemberdayaan Kelompok Wanita Tani pada Usaha Batik Tulis : Upaya peningkatan pendapatan dan kemandirian. E-Dimas : Education-Jurnal Pengabdian Kepada Masyarakat, 8(1), 44-54. https://doi.org/10.26877/e-dimas.v8i1.1373

Jakaria, R. B., Akbar, A., Kusumawardani, P. A., \& Mulyadi (2018). Micro, Small, Medium Enterprises Batik Tulis Craftsmen in Kenongo Village, Kec. Tulangan Kab. Sidoarjo [Usaha Mikro, Kecil dan Menengah Pengrajin Batik Tulis Desa Kenongo Kec. Tulangan Kab. Sidoarjo]. Proceeding of Community Development: Empowering Society Through Financial Literacy and Inclusion for Development, 2, 495-501. https://doi.org/10.30874/comdev.2018.94

Kadarisman. (2013). Manajemen Pengembangan Sumber Daya Manusia. Jakarta: PT. RajaGrafindo Persada

Karwati, L., \& Mulyono, A. D. (2018). Women Empowerment to Build Entrepreneurship. Journal of Nonformal Education, 4(2), 169-176. https://doi.org/10.15294/jne.v4i2.16005

Keputusan Bupati Nomor: 025/591 Tahun 2009 tentang penggunaan pakaian dinas bagi Pegawai Negeri Sipil (PNS) pada lingkungan Pemerintah Kabupaten Banjarnegara.

Keraf, S. (2010). Etika Lingkungan Hidup. Jakarta: Kompas Pers.

Kurniati, E. D., \& Prajanti, S. D. W. (2018). Batik SMEs Efficiency and Entrepreneurship Role in Innovation. Jejak: Journal of Economics and Policy, 11(2), 375-389. https://doi.org/10.15294/jejak.v11i2.16058

Laguia, A., García-Ael, C., Wach, D., \& Moriano, J. A. (2019). Think entrepreneur - think male": a task and relationship scale to measure gender stereotypes in entrepreneurship. International Entrepreneurship and Management Journal, 15(3), 749-772. https://doi.org/10.1007/s11365-018-0553-0

Lin, S., Yamakawa, Y., \& Li, J. (2019). Emergent learning and change in strategy: empirical study of Chinese serial entrepreneurs with failure experience. International Entrepreneurship and Management Journal. 15(3), 773792. https://doi.org/10.1007/s11365-018-0554-z 
Lukuma, C. P., Marty, R., \& Muhumuza, F. (2019). Financial inclusion and micro, small, and medium enterprises (MSMEs) growth in Uganda. Journal of Innovation and Entrepreneurship, 8(15), https://doi.org/10.1186/s13731-019-0110-2

Mahto, R.V. \& McDowell, W.C. (2018). Entrepreneurial motivation: a non-entrepreneur's journey to become an entrepreneur. International Entrepreneurship and Management Journal, 14(3), 513-526. https://doi.org/10.1007/s11365-018-0513-8

Murni, S., Rahmawati, Nurlaela, S., \& Winidyaningrum, C. (2011). Entrepreneurial Innovation In Traditional Weaving Craftsment Designed Batik for Improving the Tourism Industry in Klaten. Jurnal Ilmiah Teknik Industri, 10(2), 120-125. https://doi.org/10.23917/jiti.v10i2.1258

Musman, A., \& Arini. A. B. (2011). Batik: Warisan Adiluhung Nusantara. Yogyakarta: G-Media.

Mustika, S. (2018). Melestarikan Batik Tradisional Rifa'iyah Sebagai Identitas Budaya Komunitas Rifa'iyah. Jurnal Penelitian Komunikasi, 21(1), 29-42. https://doi.org/10.20422/jpk.v21i1.489

Nautica, S., \& Sayatman. (2019). erancangan Motif Batik dari Potensi Daerah Kabupaten Sidoarjo sebagai Cara Melestarikan dan Memperkaya Motif Batik Sidoarjo. Jurnal Sains \& Seni ITS, 8(1), 84-90, https://doi.org/10.12962/j23373520.v8i1.41627

Ngatindriatun., Ikasari, H., \& Zainuri (2014). Adaptasi Model Pemberdayaan Industri Batik Ramah Lingkungan di Jawa Tengah Guna Percepatan dan Penguatan Pembangunan Ekonomi pada Sektor Industri Tekstil di Indonesia. Prosiding SNaPP2014 Sosial, Ekonomi, dan Humaniora, 4(1), 373-380.

Pebrianasari, V., Mulyanto, E., \& Dolphina., E. (2015). Analisis Pengenalan Motif Batik Pekalongan Menggunakan Algoritma Backpropagation. Techno.COM: Jurnal Teknologi Informasi, 14(4), 281-290. https://doi.org/10.33633/tc.v14i4.973

Peraturan Bupati Banjarnegara Nomor 51 Tahun 2016 tentang pakaian dinas bagi aparatur pemerintah desa di lingkungan pemerintah Kabupaten Banjarnegara.

Permatasari, Y. (2018). State and Business Groups in the Space Industry. Andalas Journal of International Studies, 7(2), 75-88. https://doi.org/10.25077/ajis.7.2.75-88.2018

Poernomo, D., Wahono, P., \& Puspitaningtyas, Z. (2017). The Role Of Knowledge Absorption In The Mediation Of The Effect Of Social Network On The Competitive Advantages of Batik Micro Company. Archives of Business Research, 5(12), 88-100. https://doi.org/10.14738/abr.512.3933

Pudjowati, J., Suman, A., Sakti, R. K., \& Saputra, P. M. A. (2019). The Influence of Business Network and SME Empowerment towards Business Sustainability (Study of Handmade Mangrove Batik SME Surabaya). Journal of Engineering and Applied Sciences, 14(18), 6625-6633. https://doi.org/10.3923/jeasci.2019.6625.6633

Puguh, D. R. (2017). Melestarikan dan Mengembangkan Warisan Budaya: Kebijakan Budaya Semarangan Dalam Perspektif Sejarah. Jurnal Sejarah Citra Lekha, 2(1), 48-60. https://doi.org/10.14710/jscl.v2i1.14606

Purnomo, K. (2013). Nilai Kearifan Lokal dalam Batik Tradisional Kawung. Jurnal Filsafat, 23(2), 134-146. https://doi.org/10.22146/jf.13217

Puspitaningtyas, Z., Poernomo, D., \& Wahono, P. (2014). Struggle Mystical Values Craftsmen "Batik Gajah Oling" and Orientation Entrepreneurship .Conference: The 5th Sustainable Future for Human Security (SustaiN 2014) Bali, 35-42.

Samudra, A. A. (2010). Pertimbangan Kearifan Lokal Dalam Perspektif Administrasi Publik Dan Public Finance. Pidato Pengukuhan Guru Besar. Universitas Ngurah Rai Bali: Universitas Ngurah Rai, 31 Juli 2010

Savira, E. M., \& Tasrin, K. (2017). Involvement of Local Wisdom as a Value and an Instrument for Internalization of Public Service Innovation. International Journal of Administrative Science \& Organization, 24(1), 1-13. https://doi.org/10.20476/jbb.v24i1.9464

Sedarmayanti. (2013). Manajemen Sumber Daya Manusia. Bandung: Refika Aditama

Sudantoko, D. (2010). Pemberdayaan Industri Batik Skala Kecil Di Jawa Tengah: Kasus di Kabupaten dan Kota Pekalongan. Disertasi. Universitas Diponegoro.

Sugiono. (2008). Metode Penelitian Kuantitatif dan Kualitatif $R \&$ D . Bandung : Alfabeta

Sulaiman, A. I., Masrukin., M., Cusmeru, C., \& Pangestuti, S. (2016). Pemberdayaan Koperasi Pondok Pesantren sebagai Pendidikan Sosial dan Ekonomi Santri. Journal Pendidikan dan Pemberdayaan Masyarakat, 3(2), 
109-121. https://doi.org/10.21831/jppm.v3i2.11303

Sulaiman, A.I., Chusmeru., Kuncoro, B. (2019). The Educational Tourism (Edutourism) Development Through Community Empowerment Based on Local Wisdom and Food Security. International Educational Research, 2(3), 1-14. https://doi.org/10.30560/ier.v2n3p1

Suliyanto., Novandari, W., \& Setyawati, S. M. (2015). Persepsi Generasi Muda Terhadap Profesi Pengrajin Batik Tulis di Purbalingga. Jurnal Ekonomi dan Bisnis, 18(1), 153-144. https://doi.org/10.24914/jeb.v18i1.275

Suprapti, A. R., Santoso, R. E., \& Rahmawati (2016). Inovasi Desain, Teknologi, dan Pemasaran Lewat Wensite Usaha Kecil Menengah Batik Lutik (Lurik dan Batik) di Kecamatan Laweyan Surakarta. Jurnal Ekonomi dan Bisnis, 19(3), 397-412, https://doi.org/10.24914/jeb.v19i3.410

Susanti, E., \& Mas'udah, S. (2017). Model pemberdayaan perempuan pada industri rumah tangga di Provinsi Jawa Timur, Indonesia. Masyarakat, Kebudayaan dan Politik, 30(4), 353-366. https://doi.org/10.20473/mkp.V30I42017.353-366

Syamwil, R., Nurrohmah, S., \& Wahyuningsih, U. (2015). Pemberdayaan Pengrajin Batik Kendal untuk Mendukung Pariwisata. Rekayasa: Jurnal Penerapan Teknologi dan Pembelajaran, 13(1), 44-52. https://doi.org/10.15294/rekayasa.v13i1.5596

Tohari, E., \& Sugito. (2019). Innovation Needs, Social Capital, and Learning Process of Batik Craftsmen. Journal Economia: Review of Business and Economic Studies, 15(1), 17-33. https://doi.org/10.21831/economia.v15i1.22799

Török, A., Borsi, B., \& Telcs, A. (2005). Competitiveness in Research and Development. UK: Edward Elgar Publishing.

Undang-Undang Nomor 20 Tahun 2008 tentang tentang Usaha Mikro, Kecil dan Menengah.

Vitasurya, V.R., (2016). Local Wisdom for Sustainable Development of Rural Tourism, Case on Kalibiru and Lopati Village, Province of Daerah Istimewa Yogyakarta. Procedia - Social and Behavioral Sciences, 216, 97-108. https://doi.org/10.1016/j.sbspro.2015.12.014

Watson, T. J., (1995). Entrepreneurship and Professional Management: A Fatal Distinction. International Small Business Journal: Researching Entrepreneurship, 13(2), 34-46. https://doi.org/10.1177/0266242695132003

Widyastuti, T. R., \& Ardhanariswari, R. (2016). Menolak untuk Menyerah: Upaya Perempuan Perajin Batik Tulis untukTetap Menjaga Tradisi Batik Tulis di Kab. Banjarnegara. Prosiding Konferensi Nasional Sosiologi V Gerakan Sosial dan Kebangkitan Bangsa. Asosiasi Program Studi Sosiologi Indonesia. Padang 18-19 mei 2016: 99-11.

\section{Copyrights}

Copyright for this article is retained by the author(s), with first publication rights granted to the journal.

This is an open-access article distributed under the terms and conditions of the Creative Commons Attribution license (http://creativecommons.org/licenses/by/4.0/). 